\title{
有機分子自己組織化膜のトライボロジー特性
}

\author{
中 野 美 紀 \\ (独) 産業技術総合研究所 先進製造プロセス研究部門 表面機能デザイン研究グループ \\ 嶫305-8564＼cjkstart茨城県つくば市並木 1-2-1
}

(2009 年 8 月 3 日受理)

\section{Tribological Properties of Self-assembled Molecular Layers}

\begin{abstract}
Miki NAKANO
Advanced Manufacturing Research Institute, National Institute of Advanced Industrial Science and Technology (AIST) 1-2-1 Namiki, Tsukuba, Ibaraki 305-8564
\end{abstract}

(Received August 3, 2009)

\begin{abstract}
The author discuss the effects of the alkylchain length, kinds of molecules and multilayers upon the tribological properties of organosulfur self-assembled monolayers (SAMs) on Au surfaces using a conventional pin-on-plate method. The tribological properties of SAMs covalently bonded to Si and alkylsilane SAM were investigated to examine the effect of the head groups upon the tribological properties. For the alkylchian length effect, the SAMs with longer alkylchains showed lower and more stable friction coefficients than those with shorter alkylchains. For the effect of the kinds of molecules, the SAMs with phenyl rings and those with alkylchains had similar tribological behavior. However, the SAMs with phenyl rings had higher wear resistance than those with alkylchins. For the tribological properties of multilayers, the double layer with outer most layers of methyl groups showed lower friction coefficients than monolayers. The appropriately loosely packed bound molecules of the topmost layer in the double layers probably led to the decreased friction. For the effect of head group, the SAMs with Si-C bond and long alkylchains had low friction coefficients and high wear resistivity.
\end{abstract}

KEYWORDS : self-assembled monolayer (SAM), friction, Si-C bond, pin-on-plate methods

\section{1. は じめに}

有機分子の自己組織化膜 (self-assembled monolayers, $\mathrm{SAM}$ )は，金属や半導体などの固体表面上に簡単に安 定な単分子膜を生成することができる ${ }^{1)}$ 。同様な有機薄 膜である Langmuir-Blodgett（LB）膜では，単分子膜が 分子間力と弱い基板-分子間静電力で単分子膜が保たれ ているのに対して, SAM の場合には, 分子間力に加え て, 基板と有機分子間に強い化学結合が存在する（Fig. 1)。したがって, SAM は LB 膜よりも機械的に安定に なると考えられている。以上のような特長のため, SAM の応用としては, 電子線レジスト ${ }^{21}$, 有機電界効 果トランジスタ（field effect transistor, FET）のゲート電

E-mail : mi.nakano@aist.go.jp
極上への SAM 形成によるペンタセン薄膜のモルフォロ ジーの改善 ${ }^{3,4)}$ な゙が検討されている。また, トライボ ロジー的な用途としては, 微細機械, 特に MEMS の潤 滑剂 5,6$)$ などが期待できる。

SAM の摩擦特性に関する研究は, 従来, 分子膜表面 における微小領域での化学認識が目的であったため, 原 子間力顕微鏡（atomic force microscope, AFM）を用いて, 摩擦力を見積もる手法による研究が多く行われてき た フ 11)。しかし, 潤滑膜としての応用を考える場合に は, 膜全体としての巨視的な摩擦特性や耐摩耗性の評価 が重要となる。また, 通常の AFM では摺動速度が一秒 当たりマイクロメートルオーダーであるが, 実用的な潤 滑膜としては, 一秒当たりミリメートルからメートルオ ーダーのより速い摺動速度での摩擦特性を知ることが必 要となる。そこで, 著者らは, 一秒当たりミリメートル 


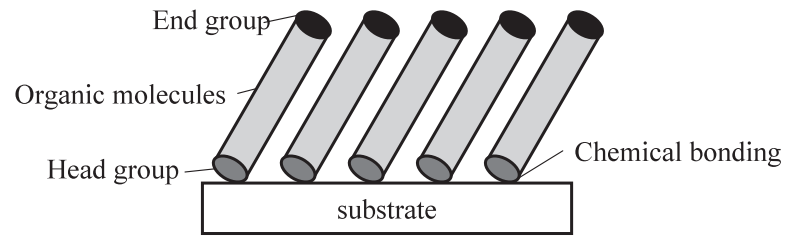

Fig. 1. Schematic diagram of self-assembled monolayer. There is chemical bonding between substrates and molecules.

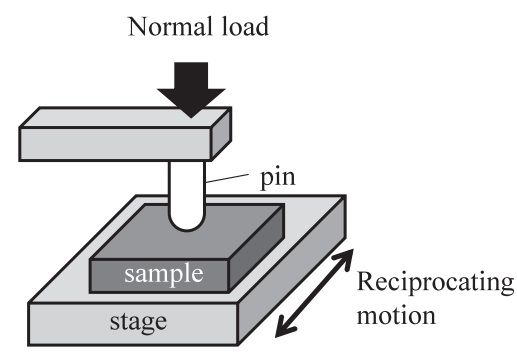

Fig. 2. Schematic diagram of pin-on-plate tribometer.

オーダーの摺動速度であるピン・オン・プレート型摩擦 試験機を用いて (Fig. 2), SAM の巨視的な摩擦特性に ついて調べてきた ${ }^{12 \sim 15)}$ 。

$\mathrm{SAM}$ 作製に用いられる基板としては，金基板および シリコンやガラス基板のものが代表的である。金基板上 の SAM には, 分子として有機硫黄化合物を用いる。こ の有機硫黄化合物は, 非常に多くの種類が市販されてい ること, SAM の作製法がシリコン上の SAM よりも容 易であることから, 系統的に分子鎖長や官能基の違いに よる影響を調べるのに適している。

一方，Si上の SAM に関しては，アルキルシランなど のシラン系の SAM が主流であり, 摩擦特性に関しても 報告されている ${ }^{25,26)}$ 。しかし, MEMS などの潤滑膜とし ての実用化を考えた場合には，シラン系 SAM では耐久 性が十分とはいえず6), より耐久性の高い SAM が必要 とされる。耐久性をあげる方法の一つとしては, Satyanarayana らによって報告されている手法で, SAMの上 にPFPE（パーフルオロポリエーテル）の新たな層を導 入する方法がある ${ }^{27,28)}$ 。もう一つは, アルケンなどの不 飽和炭化水素やアルコールなどが直接 $\mathrm{Si}$ と結合する直 接結合型の SAM を用いる手法である。直接結合型の SAM は 1990 年代に Linford と Chidseyによって発見さ れ29), その作成法や化学的特性などが調べられてい $3^{29 \sim 33)}$ 。その結果, 直接結合型の SAM がシラン系 SAM よりも化学的に高い耐性を持っていることが報告 されている ${ }^{31}$ 。さらに, 直接結合型の SAMでも分子・ 基板間の結合であるへッドグループが異なると化学的な 耐性が異なることがわかっており ${ }^{33)}$, ヘッドグループの
違いにより膜の特性が異なる可能性が示唆される。

本稿では，ピン・オン・プレート法を用いて金基板上 の SAM および $\mathrm{Si}$ 基板上の SAM の摩擦特性に関する研 究について紹介する。金上の SAM については, 第一 に, 直鎖の分子構造をもつアルカンチオール SAM の摩 擦特性の鎖長依存性, 第二に, SAM の摩擦特性に対す る分子種依存性, 最後に, アルカンチオール自己組織化 多層膜の摩擦特性について, Si 上の SAM については, ヘッドグループの摩擦特性への影響について述べていき たい。

\section{2. 金上の自己組織化膜の摩擦特性}

\section{1 アルカンチオール SAM の摩擦特性 : アルキル 鎖長依存性}

金上のアルカンチオール SAM の摩擦特性に関して は，これまでに多数調べられており，AFMを用いた研 究などから, アルキル鎖長の長い分子の方が低い摩擦係 数を示す傾向があることが報告されている ${ }^{11)}$ 。筆者ら は, 巨視的な摩擦特性においても同様な摩擦特性がある かを明らかにするために, ピン・オン・プレート型摩擦 試験機を使用して, 二種類の鎖長のアルカンチオールに ついて, 摩擦係数の鎖長依存性を調べた ${ }^{12)}$ 。

使用したアルカンチオール分子はドデカンチオール $\left(\mathrm{DDT}: \mathrm{CH}_{3}\left(\mathrm{CH}_{2}\right)_{11} \mathrm{SH}\right)$ とオク夕デカンチオール $\left(\mathrm{ODT}: \mathrm{CH}_{3}\left(\mathrm{CH}_{2}\right)_{17} \mathrm{SH}\right)$ である。 $\mathrm{SAM}$ の作製は浸漬法 により行った。用いた金基板は, ガラス基板に金を蒸着 したもので, 前処理としては, UV/オゾン処理後, エ夕 ノール洗浄を行った。基板の浸漬は室温で行い, 溶媒に エタノールを用いた $1 \mathrm{mM}$ のアルカンチオール溶液に 24 時間浸漬した。溶液から基板を取り出した後, エ夕 ノールでリンスをした。また, 摩擦試験はすべて大気中 で行った。

Fig. 3 に摩擦係数の時間変化を示す。 3 本のプロット は同じ試料上の異なる場所で行った摩擦試験の結果を示 している。鎖長の長い ODT SAM は比較的低い摩擦係数 0.2-0.3を示し, データのばらつきも小さかった（Fig. 3 (a))。一方, 鎖長の短い DDT では, データのばらつき が大きく高い摩擦係数を示すものも存在する（Fig.3 (b))。次に，摩擦係数に鎖長依存性があらわれた原因を 調べるために, 摩擦前後の SAM の化学状態を X 線光電 子分光法 (X-ray photoelectron spectroscopy, XPS) によっ て調べた。その結果, 鎖長の短い DDT SAM の場合にの み, 摩擦試験後に一部の硫黄が酸化されている様子が観 察された（Fig. 4)。

アルカンチオールのような直鎖の分子においては, 分 子間に分子鎖長に応じたファンデルワールスカが働くこ 

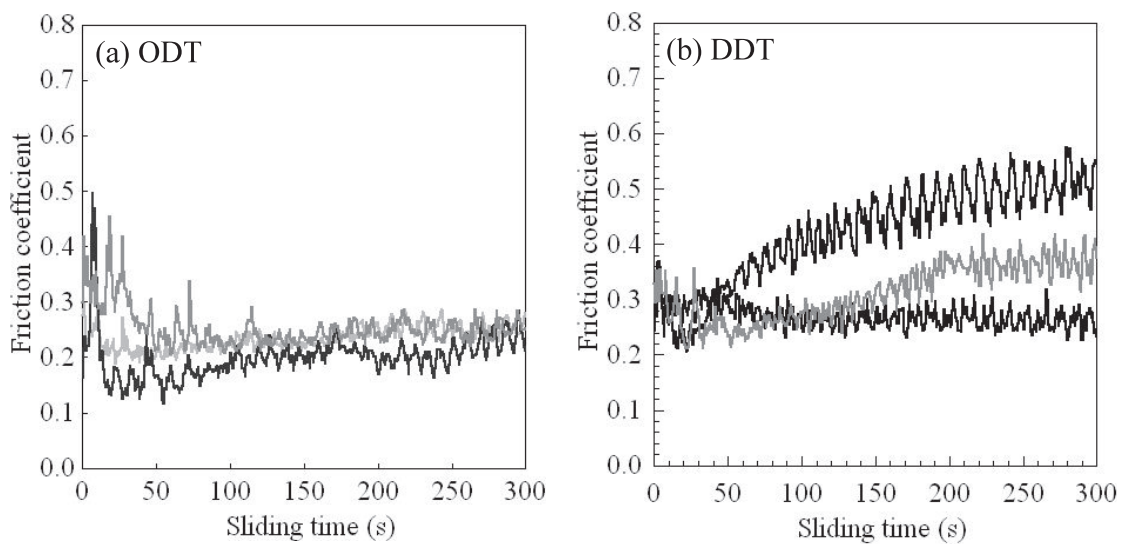

Fig. 3. Friction coefficients of ODT SAMs (a) and DDT SAMs (b) as a function of sliding time. These three friction test runs were performed at different positions on the same sample.
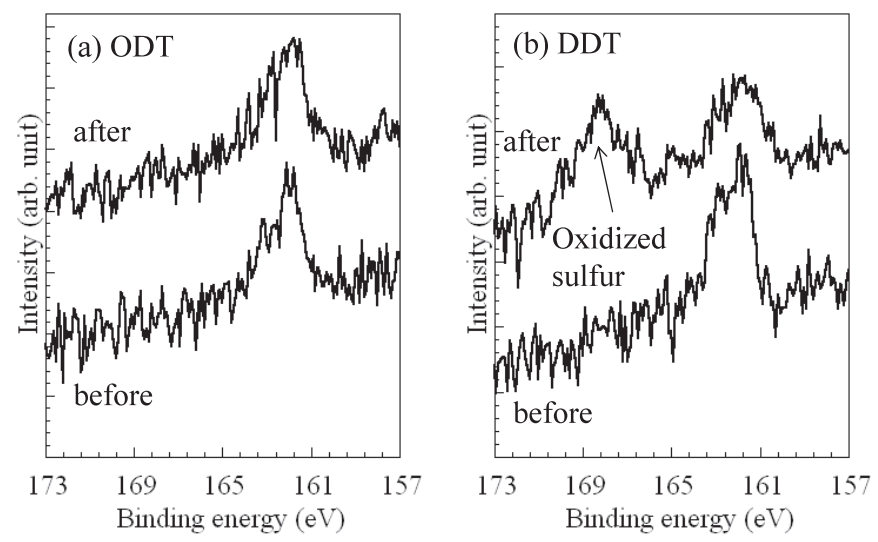

Fig. 4. XPS spectra of ODT SAMs (a) and DDT SAMs (b) in the $S(2 p)$ region before and after friction tests.

とが報告されている ${ }^{16)}$ 。したがって，鎖長が短い分子か らなるSAM の場合には，鎖長が長い分子からなる SAM に比べて，分子配向が無秩序であると言われてい る。このため，鎖長が短い分子からなる SAM の場合に は，摩擦時にピンが分子膜を突き抜け，分子全体が雲囲 気中の水蒸気などとトライボケミカル反応を起こすもの と考えられる。Fig. 4（b）の DDT SAMに打いて，基板 と直接結合している硫黄が一部酸化している結果も, こ のことを示唆している。さらに，分子の配列が無秩序で ばらつきがあることから，摩擦係数の值にもばらつきが あらわれたものと考えられる。一方，鎖長の長い分子か らなる SAM の場合には，分子間相互作用が強く働くた めに，耐久性の高い分子膜が形成したと考えられる。以 上の結果より, 分子膜の摩擦特性と分子膜を構成する分 子の化学状態には，密接な関係があり，鎖長の長い分子 からなる SAM の方が安定な摩擦特性を示す潤滑膜が形 成されるものと考えられる。

\section{2 ターフェニルメタンチオール SAM の摩擦特性 : 分子種依存性}

近年，多芳香環を含む分子から作製したSAM に関す

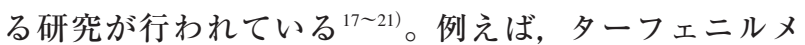
タンチオール（TP1: $\mathrm{C}_{6} \mathrm{H}_{5}\left(\mathrm{C}_{6} \mathrm{H}_{4}\right){ }_{2} \mathrm{CH}_{3} \mathrm{SH} ）$ から作製し たSAM については，アルカンチオール SAM よりも紫 外光や熱に関して高い耐性を示すことが報告されてい る ${ }^{17}$ 18)。したがって，TP1 SAM の摩擦特性が高い耐摩 耗性を示せば，紫外光や熱にも耐性のある潤滑膜として 使用できる可能性がでてくる。筆者は，TP1 SAM およ び，比較として，直鎖の ODT SAM についてピン・オ ン・プレート法を使用して，摩擦特性を調べた ${ }^{13)}$ 。

SAM の作製法抒よび金基板は 2.1 と同様であるが, TP1 SAM の作製に用いた溶媒がジクロロメタンである 点のみ異なる。Fig. 5 は TP1 SAM および ODT SAM の 摩擦係数の時間変化を表している。二本のプロットは同 じ試料上の異なる場所で摩擦試験を行った結果である。 

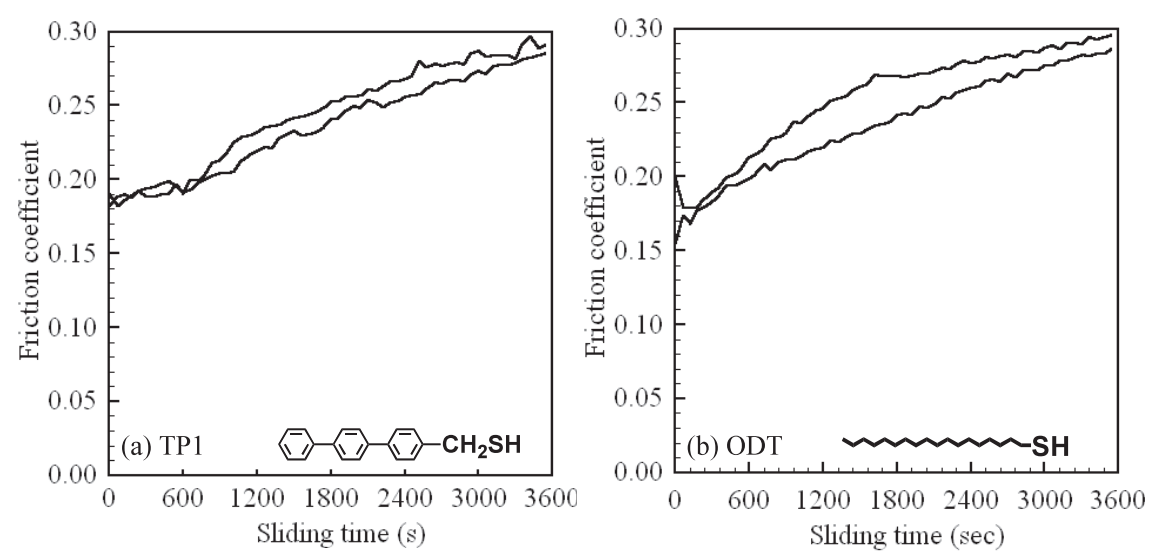

Fig. 5. Friction coefficients of two sliding runs measured using a pin-on-plate tribometer on TP1 : (a) and ODT SAMs : (b) as a function of sliding time. These two friction test runs were performed at different positions on the same sample.

Table 1. XPS peak area ratio of $\mathrm{C}(1 \mathrm{~s}) / \mathrm{Au}(4 \mathrm{f})$ and decrease ratio of XPS peak area ratio after sliding. In all the conditions, we measured two or three samples.

\begin{tabular}{ccccc}
\hline \multirow{2}{*}{ Sliding time(h) } & \multicolumn{2}{c}{ XPS peak area ratio } & \multicolumn{2}{c}{ Decrease ratio(\%) } \\
\cline { 2 - 5 } & TP1 & ODT & TP1 & ODT \\
\hline 0 & $1.63 \pm 0.06$ & $2.01 \pm 0.08$ & & \\
1 & $1.54 \pm 0.09$ & $1.73 \pm 0.09$ & 5.5 & 13.9 \\
10 & $1.22 \pm 0.04$ & $1.25 \pm 0.03$ & 25.2 & 37.8 \\
\hline
\end{tabular}

TP1 と ODT では両者ともほとんど同じ傾向を示してい る。次に, XPS を使用して, 摩擦による表面の分子吸 着量の変化を調べた。その結果を Table 1 に示す。Table 1 は XPS で得られた C (1s)/Au (4f) のピーク面積比およ びピーク面積比の減少割合を表している。ピーク面積比 は分子の表面吸着量, ピーク面積比の減少割合は分子の 表面吸着量の減少割合の指標となる。いずれの表面にお いても, 摩擦により C $(1 \mathrm{~s}) / \mathrm{Au}(4 \mathrm{f})$ のピーク面積比が減 少しており, 吸着している分子量が減少していることを 示している。しかしながら, ピーク面積比の減少割合を TP1 SAM と ODT SAM で比較すると, ODT SAM の方が 大きい。したがって, 摩擦に対する膜としての耐久性は TP1 SAM の方が ODT SAM よりも優れていると考えら れる。さらに, TP1 SAM の長さは $1.5 \mathrm{~nm}$ と DDT SAM $(1.44 \mathrm{~nm})^{22)}$ とほぼ等しい。そのため, 多芳香環を含む 分子を用いることで, 耐久性が高く, より薄い潤滑膜の 作製が期待できる。

\section{3 自己組織化多層膜の摩擦特性}

2.1 および 2.2 で単分子膜の摩擦特性について述べて きた。得られた摩擦係数は, 低いもので 0.2-0.3である ため, 潤滑膜としての実用化を考える場合には, より低 い摩擦係数が望まれる。筆者は, より低い摩擦係数を得 るために，二層構造の多層膜に着目した。HDI で用い
られるPFPE の場合には, 固定層と流動層の二層構造 で, 低摩擦を得られることが報告されている ${ }^{23)}$ 。そこ で, 自己組織化法によって二層構造の分子膜を作成する ことで同様な効果を期待できると考元, 従来から報告さ れている自己組織化多層膜の手法を用いて ${ }^{24)}$ 二層構造の 分子膜を作成し，摩擦特性の評価を行った ${ }^{14)}$ 。Fig. 6 に 作成した多層膜の模式図を示す。一層目には, 雨端にカ ルボン酸とメルカプト基を持つメルカプトヘキサデカン 酸（MHA : $\left.\mathrm{COOH}\left(\mathrm{CH}_{2}\right)_{15} \mathrm{SH}\right)$, 二層目には MHA あるい は, 両端にメチル基とメルカプト基を持つ ODTを使用 した。一層目と二層目の間には，Cuイオンを導入した。 二層目の分子として, 表面エネルギーが低いメチル基を 末端に持つ ODT を使用することで, 低摩擦を実現でき ると考えた。

単層膜の作製手法，抒よび，用いた金基板は 2.1 と同 様である。多層膜の作製手法については, 作製した単層 膜を $1 \mathrm{mM}$ の酢酸銅溶液（溶媒：エタノール）に 5 分浸 漬した後, エタノールでリンスし, 二層目の $1 \mathrm{mM}$ の ODT あるいは, MHA 溶液（溶媒 : エタノール）に 24 時間，浸漬した後，エタノールでリンスした。

Fig. 7 に ODT/MHA 二層膜㧍よび MHA/MHA二層 膜, 比較として ODT 単層膜, MHA 単層膜の摩擦係数 の時間変化を示している。最上層が MHA の場合には, 
単層膜，二層膜において大きな違いはみられなかった。 一方, 最上層が ODT の場合には, 試験開始直後はほぼ 同じ值であったが, 二層膜の場合には, その後, 摩擦係 数が減少していったのに対し, 単層膜の場合には, 除々 に増加していった。

続いてXPS のピーク面積比より摩擦前後の分子膜の 平均膜厚を求めた。その結果を Table 2 に示す。MHA, ODT 最上層のいずれの場合にも, 単層膜の摩擦による 平均膜厚の減少に比べて, 二層膜の平均膜厚の減少は著 しく大きいことがわかった。Table 2 の結果より一層目 と二層目の分子の吸着力が異なることが推測される。す なわち, 一層目の分子の基板に対する吸着力に比べて, 二層目の分子の一層目の分子に対する吸着力が弱いこと

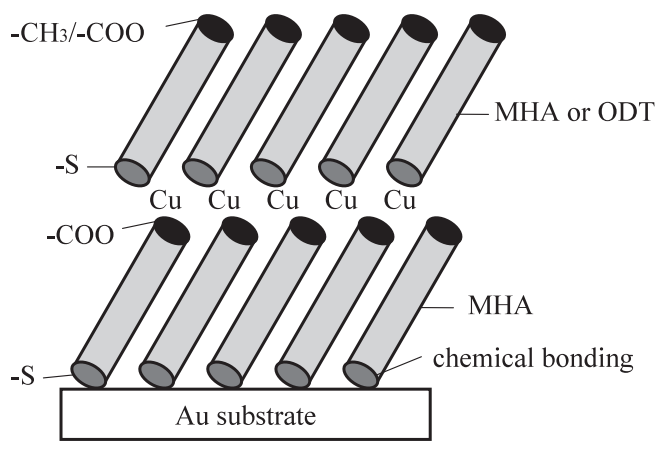

Fig. 6. Schematic diagram of self-assembled double layer.
が推測される。この推測より，摩擦により脱離が起こる 分子の量は一層目よりも二層目の分子の方が多いと考え られ，摩擦により最上層の分子密度が踈になり，そのこ とが摩擦係数の減少に関与している可能性が考えられ る。そこで, ODT/MHA二層膜において, 最上層の ODT 溶液の浸漬時間を変化させることにより, ODT 分 子の吸着量を変化させた。その時の平均摩擦係数を Fig. 8 に示す。浸漬時間が 24 時間の場合に, 摩擦係数が最 も低くなることがわかった。この結果より，最上層の ODT 分子が適度な吸着量である時, すなわち, 最上層

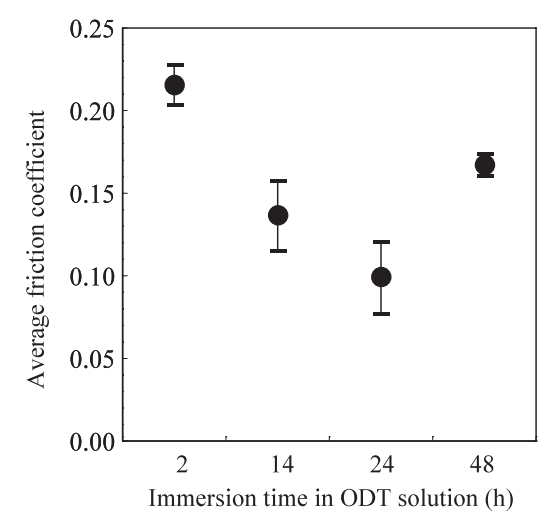

Fig. 8. Average friction coefficients of ODT ended selfassembled double layers for $30 \mathrm{~min}$ as a function of immersion time in ODT solution.
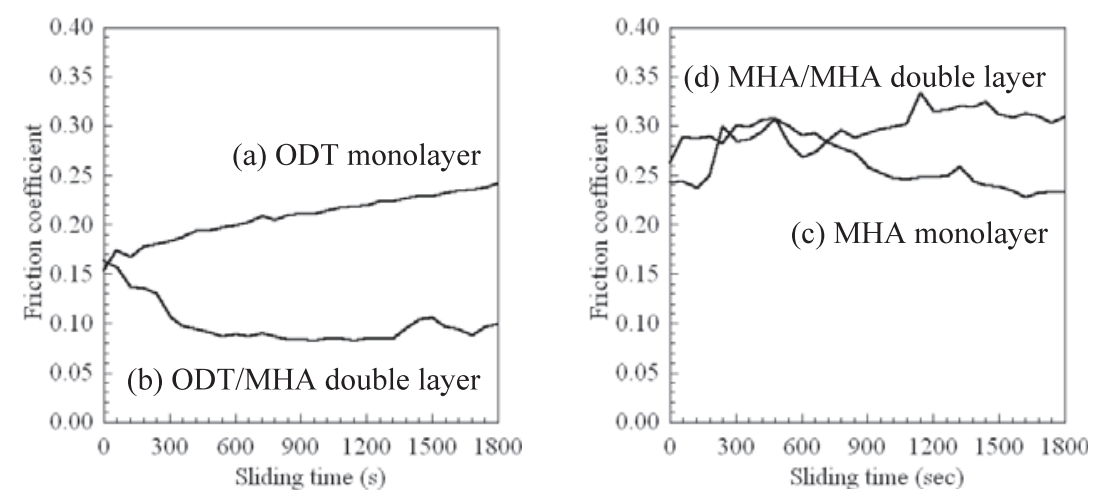

Fig. 7. Friction coefficients of self-assembled layers as a function of sliding time : (a) ODT monolayer, (b) ODT/MHA double layer, (c) MHA monolayer, (d) MHA/MHA double layer.

Table 2. Film thickness (nm) of self-assembled layers estimated from the XPS $\mathrm{C}(1 \mathrm{~s}) / \mathrm{Au}(4 \mathrm{f})$ ratios.

\begin{tabular}{ccccc}
\hline & $\begin{array}{c}\text { ODT } \\
\text { monolayer }\end{array}$ & $\begin{array}{c}\text { ODT/MHA } \\
\text { double layer }\end{array}$ & $\begin{array}{c}\text { MHA } \\
\text { monolayer }\end{array}$ & $\begin{array}{c}\text { MHA/MHA } \\
\text { double layer }\end{array}$ \\
\hline $\begin{array}{c}\text { Before } \\
\text { friction }\end{array}$ & 2.20 & 4.63 & 2.62 & 5.06 \\
\hline $\begin{array}{c}\text { After friction } \\
(30 \mathrm{mN}, 1 \mathrm{~h})\end{array}$ & 1.97 & 2.96 & 2.14 & 3.73 \\
\hline
\end{tabular}


の ODT 分子の密度が適度に疎であるときに, 低い摩擦 係数を示すと考えられる。

次に, Fig. 7 における最上層の分子種による摩擦係数 の違いであるが, ODT が最上層の場合には，分子膜は 踈水性で低い表面エネルギーである一方，MHA の場合 には, 親水性で表面エネルギーは高いと考えられる。表 面エネルギーが高い方が, 高い摩擦を示すことが報告さ れている ${ }^{16,34)}$ このことは, Fig. 7 において MHA 最上 層の分子膜の方が ODT 最上層の分子膜よりも高い摩擦 係数を示すことと一致する。

\section{Si 上の自己組織化膜の摩擦特性}

$\mathrm{Si}$ 上の SAM については, シラン系 SAM に加え, 近 年，直接結合型の SAM についても調べられてきてい る。特に，直接結合型の SAM については分子・基板間 の結合であるへッドグループが異なると化学的な耐性が 異なることがわかっており ${ }^{33)}$, ヘッドグループの違いに より膜の特性が異なる可能性が示唆される。そこで, 筆 者は直接結合型の SAM に着目し, その摩擦特性評価を ピン・オン・プレート法により行い, ヘッドグループの 違いによる摩擦特性への影響について検討した。

ヘッドグループの影響を調べるために，ヘキサデセン (HD) SAM，ヘキサデカノール（HDO）SAM，オクタ デカントリクロロシラン（ODS）SAM の三種類の SAM を使用した。この三種類の SAM は，末端基がメチル基 と等しく, 鎖長が炭素数 16-18 と近いもので, 分子・基 板間の結合であるへッドグループが異なる。ヘッドグル ープは HD では Si-C, HDO では Si-O-C, ODS では OSi-O である。また，直接結合型の SAM において鎖長の 摩擦特性依存性を検討するために, ヘッドグループが Si-C であるドデセン（DD）SAMにおいても摩擦特性を 調べた。基板には， $\mathrm{Si}$ （111）単結晶を用いた。 HD, HDO, DD の直接結合型 SAM の作製には，水素終端 Si （111）基板を $423 \mathrm{~K}$ の $100 \mathrm{mM}$ の溶液（溶媒：メシチレ ン）に 2 時間浸漬し, 基板を取り出した後, ヘキサン, エタノール，超純水の順にリンスした。ODS のアルキ ルシラン SAM は，UV/オゾン処理をした $\mathrm{Si}$ (111) 基 板を $1 \mathrm{mM}$ の溶液（溶媒：ヘキサデセン）に室温で 24 時間浸漬し，基板を取り出した後，ヘプタン，エタノー ル，超純水の順にリンスした。

Fig. 9 は HD SAM, DD SAM, HDO SAM, ODS SAM および基板である $\mathrm{Si}$ （111）表面における摩擦倸数の時 間変化を表している。基板である $\mathrm{Si}$ 表面と DD SAM は 摩擦試験開始直後に摩擦係数が急激に上昇している。 HDO および ODS SAM では，特定の時間までは安定な 摩擦係数を示しているが, その後, 急激に摩擦係数の上

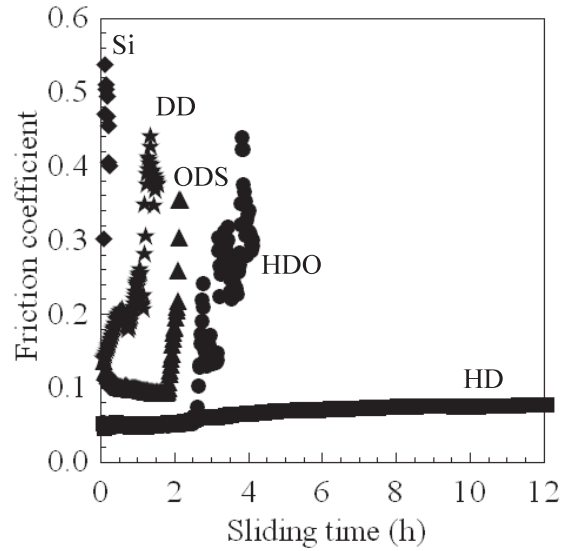

Fig. 9. Friction coefficients of $\mathrm{HD}, \mathrm{DD}, \mathrm{HDO}, \mathrm{ODS}$, and $\mathrm{Si}$ (111) surfaces as a function of sliding time. Normal load was $98 \mathrm{mN}$ and average sliding speed was 2 $\mathrm{mm} / \mathrm{sec}$.

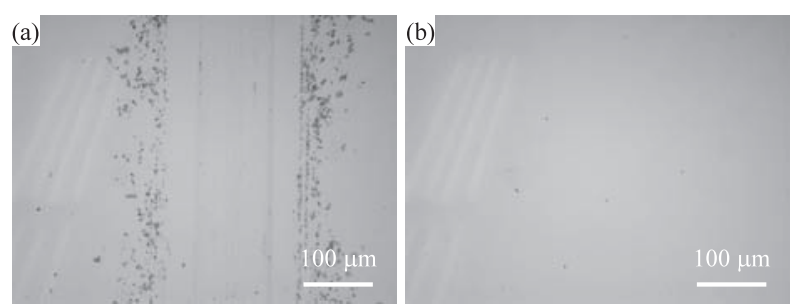

Fig. 10. Optical microscope images of HDO (a) and HD SAM surfaces (b) after friction tests for $5 \mathrm{~h}$ (a) and $10 \mathrm{~h}$ (b) under a load of $98 \mathrm{mN}$.

昇が観察される。一方，HD SAM においては 12 時間を 超えても摩擦係数は安定な值を示しており, 摩擦係数の 急激な上昇は見られなかった。次に，摩擦後の表面の光 学顕微鏡像を Fig. 10 に示す。HDO SAM においては, 摩耗痕がはっきり観察され，DD SAM および ODS SAM でも同様な摩耗痕が観察された。一方, HD SAM にお いては，摩耗痕が全く観察されなかった。これらの結果 より，HDO，DD および ODS SAM において摩擦係数の 急激な上昇が起こったのは，表面の分子が摩擦により脱 離し，表面に摩耗が起こったものと考えられる。一方， HD SAM においては, 摩擦後も分子が表面に残ってい たために, 摩耗が起こらず, 摩擦係数も安定な值を保っ ていたことと考えられる。以上の結果より, 同程度の長 さの鎖長の SAM の場合には， Si-C 結合により基板に吸 着している SAM が， Si-O-C 結合により基板に吸着して いる SAM やアルキルシラン SAM よりも高い耐摩耗性 も持つことがわかった。また，同じヘッドグループ，す なわち，分子・基板間の吸着に関与する官能基が等しい 場合でも鎖長が DD のように短い場合には，耐摩耗性は 低くなり, SAM の耐摩耗性にはヘッドグループに加え, 
分子鎖長が重要であるということが示唆される。以上よ り, Si-C 結合をもち, 鎖長が炭素数で 16 程度の SAM を用いることで，アルキルシラン SAM よりも耐摩耗性 が高く, 長時間安定な摩擦係数を示す SAM を作製でき ることがわかった。

\section{4. ま め}

本稿では，金上および $\mathrm{Si}$ 上の有機分子自己組織化膜 の摩擦特性に関する研究の紹介をした。潤滑膜としての 応用を考える際には，分子鎖長・ヘッドグループの選択 が重要となること, 分子種を代えることでさらに耐久性 の高い分子膜が作成できる可能性があることがわかっ た。今後は,さらに過酷な摩擦条件での耐久試験や耐久 性を向上させるための分子種の選択，例えば，フッ素を 含む分子，によって，より薄い膜で低摩擦・高耐摩耗性 を実現できる可能性があると考えられる。また，分子膜 の物理化学的, 表面科学的特性評価も重要であり, これ らの評価を加えることで分子種や材料の選択に関する新 たな知見が得られることが期待できる。

\section{謝 辞}

これらの研究については, 石田敬雄氏, 安藤泰久氏, 三宅晃司氏(産総研先進製造プロセス研究部門), 佐々 木信也教授 (東京理科大学), 杉村博之教授 (京都大 学), 沼田俊充氏 (日産アーク), 佐野光氏 (産総研ユビ キタスエネルギー研究部門）ら, 多くの方々からご協力 を頂いた。この場を借りて深く感謝の意を示したい。

\section{文献}

1) A. Ulman : "An Introduction to Ultrathin Organic Films from Langmuir-Blodgett to Self-Assembly” (Academic Press Inc., San Diego, 1991) p. 279.

2) T. Tanii, T. Hosaka, T. Miyake and I. Ohdomari : Jpn. J. Appl. Phys. 43, 4396 (2004).

3) Y.-Y. Lin, D.J. Gundlach, S.F. Nelson and T.N. Jackson : IEEE Electron Device Lett. 18, 606 (1997).

4) S. Kobayashi, T. Nishikawa, T. Takenobu, S. Mori, T. Shimoda, T. Mitani, H. Shimotani, N. Yoshimoto, S. Ogawa and Y. Iwasa : Nature Materials 3, 317 (2004).

5) U. Srinivasan, M.R. Houston, R.T. Howe and R. Maboudian : J. Microelctromech. Syst. 7, 252 (1998).

6) M.P. de Boer and T.M. Mayer: MRS Bulletin 26, 302 (2001).

7) T. Ishida, S. Yamamoto, W. Mizutani, M. Motomatsu, H. Tokumoto, H. Hokari, H. Azehara and M. Fujihira: Langmuir 13, 3261 (1997).

8) H.I. Kim, T. Koini, T.R. Lee and S.S. Perry : Langmuir 13, 7192 (1997).
9) K. Hayashi, H. Sugimura and O. Takai : Jpn. J. Appl. Phys. 40, 4344 (2001).

10) A. Takahara, K. Kojio, S.-R. Ge and T. Kajiyama : J. Vac. Sci. Tech. A 14, 1747 (1996).

11) A. Lio, D.H. Charych and M. Salmeron : J. Phys. Chem. B 101, 3800 (1997).

12) M. Nakano, T. Ishida, T. Numata, Y. Ando and S. Sasaki : Jpn. J. Appl. Phys. 42, 4734 (2003).

13) M. Nakano, T. Ishida, T. Numata, Y. Ando and S. Sasaki : Jpn. J. Appl. Phys. 43, 4619 (2004).

14) M. Nakano, T. Ishida, T. Numata, Y. Ando and S. Sasaki : Appl. Surf. Sci. 242, 287 (2005).

15) M. Nakano, T. Ishida, H. Sano, H. Sugimura, K. Miyake, Y. Ando and S. Sasaki : Appl. Surf. Sci. 255, 3040 (2008).

16) R.W. Carpick and M. Salmeron : Chem. Rev. 97, 1163 (1997).

17) T. Ishida, H. Fukushima, W. Mizutani, S. Miyashita, H. Ogiso, K. Ozaki and H. Tokumoto: Langmuir 18, 83 (2002).

18) T. Ishida, M. Sano, H. Fukushima, M. Ishida and S. Sasaki : Langmuir 18, 10496 (2002).

19) B. Bhushn and H. Liu : Phys. Rev. B 63, 245412 (2001).

20) N. Garg, E. Carrasquillo-Molina and T.R. Lee : Langmuir 18, 2717 (2002).

21) W. Azzam, B.I. Wehner, R.A. Fisher, A. Terfort and C. Woll : Langmuir 18, 7766 (2002).

22) C.D. Bain, E.B. Troughton, Y.-T. Tao, J. Evall, G.M. Whitesides and R.G. Nuzzo : J. Am. Chem. Soc. 111, 321 (1989).

23) X. Ma, H. Tang and J. Giu : Symposium on Interface Tribology, ASME 10, 61 (2000).

24) S.D. Evans, A. Ulman, K.E. Goppert-Berarducci and L.J. Gerenser : J. Am. Chem. Soc. 113, 5866 (1991).

25) Y. Ando, Y. Inoue, K. Kakuta, T. Igari and S. Mori : Trobo. Lett. 27, 13 (2007).

26) M. Masuko, H. Miyamoto and A. Suzuki : Tribo. Int. 20, 1587 (2007).

27) N. Satyanarayana and S.K. Sinha : J. Phys. D Appl. Phys. 38, 3512 (2005).

28) N. Satyanarayana, N.N. Gosvami, S.K. Sinha and M.P. Srinivasan : Philos. Mag. 87, 3209 (2007).

29) M.R. Linford and C.E.D. Chidsey : J. Am. Chem. Soc. 115, 12631 (1993).

30) M.R. Linford, P. Fenter, P.M. Eisenberger and C.E.D. Chidsey : J. Am. Chem. Soc. 117, 3145 (1995).

31) N. Saito, S. Youda, K. Hayashi, H. Sugimura and O. Takai : Surf. Sci. 532-535, 970 (2003).

32) X. Wallart, C. Henry de Villeneuve and P. Allongue : J. Am. Chem. Soc. 127, 7871 (2005).

33) H. Sugimura, H. Sano, K.-H. Lee and K. Murase : Jpn. J. Appl. Phys. 45, 5456 (2006).

34) J.-B.D. Green, M.T. McDermott, M.D. Porter and L.M. Siperko : J. Phys. Chem. 99, 10960 (1995). 